Pasture and Forage Crop Pests

\title{
BLACK FIELD CRICKETS CONSUME OVERSOWN PASTURE SEED
}

\author{
R.H. BLANK, D.S. BELL and H.M. MORGAN \\ Agricultural Research Division, MAF, Whangarei
}

Summary

At two sites with bare weedy pasture, daily seed theft from seed lines placed on April oversown plots rose from a low level (0-12\%) to the level of theft from seed lines on untreated (not oversown) plots (77-100\%) within 9 days. This corresponded to an almost complete elimination of the broadcast pasture seed $(33 \mathrm{~kg} / \mathrm{ha})$. At a third site, which had a ryegrass (Lolium perenne) dominant pasture, daily seed theft from seed lines in the oversown plot had risen by $10 \%$ after 9 days but was still below the level in the untreated plot. Black field crickets (Teleogryllus commodus) were responsible for most of the seed theft at all three Northland sites.

\section{INTRODUCTION}

Black field crickets may severely damage pasture during summer and autumn (Blank 1979). Damage is caused by crickets eating pasture as well as pasture seed and seedlings. Such pastures become weed infested, have considerably reduced production, and need to be renovated (Blick 1959; Smith and Harrow 1971).

Pasture renovation in Northland is often done by broadcasting pasture seed particularly on hilly areas which cannot be easily cultivated. On flatter areas broadcast seed may be 'Dutch Harrowed' into existing pasture.

The aim of this study was to evaluate pasture seed loss when seed was broadcast onto black field cricket damaged pasture.

\section{METHOD}

The three sites chosen for this trial were on clay soils which, had cracked over the dry 1978-79 summer and were known to harbour black field crickets. Site 1 was located near Kiripaka on a steep hillside facing south on a Whareora clay loam. Site $\mathbf{2}$ was located near Mata on a flat lowland area on a Waipu clay. Site 3 was on an estuarine flat of Kaipara clay near Dargaville. The pasture at sites 1 and 2 was comprised largely of bare ground and flatweeds whilst site 3 contained a ryegrass and white clover (Trifolium repens) dominant pasture but also had patches of bare ground. At each site two $20 \times 20 \mathrm{~m}$ areas that were 30 to $80 \mathrm{~m}$ apart, of similar pasture type and degree of cracking, were selected. A pasture seed mix of 'Grasslands Nui' ryegrass $(25 \mathrm{~kg} / \mathrm{ha})$, 'Grasslands G16' cocksfoot (Dactylis glomerata) ( $2 \mathrm{~kg} / \mathrm{ha})$, 'Grasslands Huia' white clover $(5 \mathrm{~kg} / \mathrm{ha})$, and 'Woogenellup' subterranean clover (T. subterraneum) $(1 \mathrm{~kg} / \mathrm{ha})$ was broadcast in one of these plots at each site on April 21979.

Four replicates ( $10 \mathrm{~m}$ apart) of seed lines were laid out in the central area of both the oversown and untreated plots. Each replicate consisted of four seed lines placed 50 $\mathrm{mm}$ apart with each seed line comprising ten seeds of one of the broadcast pasture species placed $20 \mathrm{~mm}$ apart. The position of each seed was marked with a stainless steel pin. Each replicate was covered by a plastic covered wire cage which protected seed from being displaced by wind and rain or being removed by birds but allowed free entry to crickets. Seed lines were checked each day for missing seeds which were replaced. Daily seed theft was recorded continuously at site 1 and with a break at sites 2 and 3 over a 9 day period.

Ten pitfall traps were placed at regular intervals within each plot at the start of the trial and were cleared after 3 days. Pitfall traps consisted of an 'Agee' preserving jar

Proc. 33rd N.Z. Weed and Pest Control Conf. 
containing $50 \mathrm{ml}$ of a saturated picric acid solution, a plastic funnel and a tin lid attached $(20 \mathrm{~mm})$ above an Agee screw band.

Maximum and minimum air temperature from within the cages as well as rainfall and soil moisture were recorded.

Seed theft

\section{RESULTS AND DISCUSSION}

Daily seed theft from the seed lines placed in the oversown plots at sites 1 and 2 rose from a low level $(0-12 \%)$ to the level of the untreated plots within 9 days (Fig. 1).

Fig. 1. Daily seed theft from seed lines on oversown and untreated plots
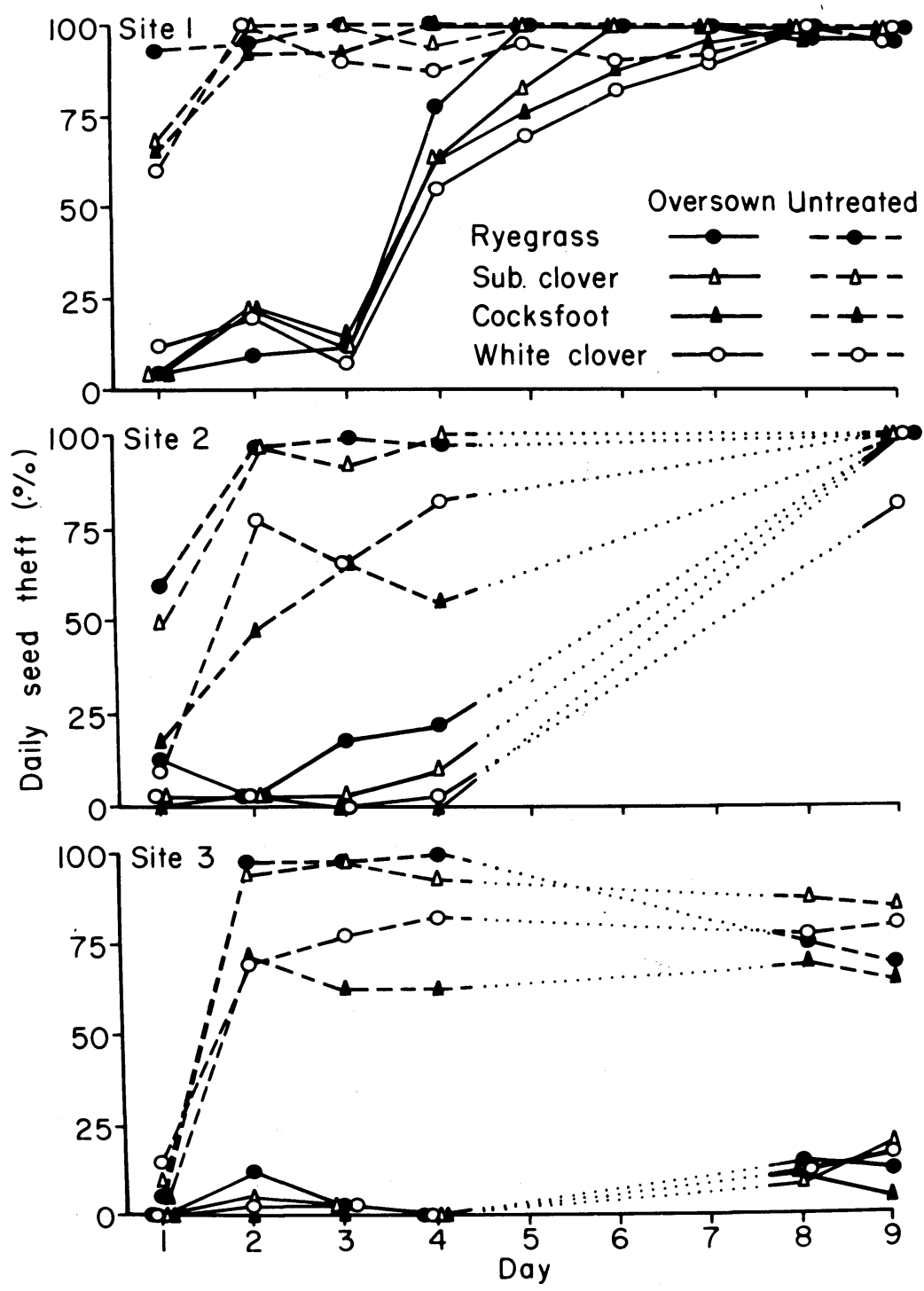


\section{Pasture and Forage Crop Pests}

This corresponded to the almost complete elimination of the broadcast ryegrass, cocksfoot and subterranean clover seeds from the oversown plots. Some white clover seeds which had started to germinate were still present.

Daily seed theft from seed lines placed in the oversown plot at site $\mathbf{3}$ had risen by $10 \%$ after 9 days but was well below the levels in the untreated plots (Fig. 1). Seed was still present on the oversown plots during this time. The low daily seed theft values obtained for the oversown plot at site 3 may have been a result of low black field cricket numbers in the oversown plots (Table 1) which was caused by insecticidal baits being spread in the neighbouring paddock close to the oversown area. In addition, the large amounts of ryegrass, which is a favoured food plant for black field crickets (Blank et al 1980), may have reduced feeding on broadcast seed at site 3 .

TABLE 1: Mean No. of black field crickets caught per pitfall trap in 3 days in oversown and untreated plots

\begin{tabular}{lccr}
\hline & Site 1 & Site 2 & Site 3 \\
\hline Untreated & 4.0 & 21.9 & 20.6 \\
Oversown & 1.1 & 2.2 & 3.0 \\
\hline
\end{tabular}

The relatively small size of the oversown plots $(0.04$ ha) may have drawn seed predators into the plots from surrounding areas, in which case the estimates of seed loss may be overestimates compared to paddock-scale oversowing, Pitfall traps were removed after three days so as not to deplete the resident black field cricket populations. Thus, no measure of immigration into the plots was available. Even so, removal of seed from the oversown plots was very rapid and was mirrored by the daily seed theft values obtained from the seed lines.

\section{Seed predators}

Black field crickets were observed on all plots throughout the trial and were observed feeding on the seed lines at sites 1 and 2 . The pitfall catches (Table 1) indicate that cricket numbers and/or activity were greater on the untreated than oversown plots, which suggests that cricket activity was reduced where there was an abundance of the highly favoured seed. Black field crickets were boldest in the untreated plot at site 1 , which had very little alternative food sources, often feeding on the seed lines within minutes of them being set out. Black field crickets usually consumed the ryegrass and cocksfoot seed near the seed lines leaving the seed husks close to the marking pins, whereas the legume seeds were usually removed from the seed lines. Grass seed which had been fed on by the black field crickets had to be carefully checked as typically the caropsis only was consumed leaving the outer husks in a near undamaged state. Legume seed feeding damage was more obvious as the smooth outer seed coating had to be torn apart to expose the caropsis. Ryegrass seed was most favoured by the black field crickets closely followed by subterranean clover seed with cocksfoot and white clover seed the least favoured (Fig. 1).

Birds must have contributed to seed loss from the oversown plots but not from the protected seed lines, at site 1, as four birds, yellowhammers (Emberiza citrinella), were observed on day four feeding on oversown seed at that site. Bird droppings were quite numerous on the oversown area after 9 days (approximately one dropping per $\mathrm{m}^{2}$ ). Seed broadcast near cracks was consumed before seed away from cracks. This suggests that black field crickets, which shelter down the cracks, contributed more to seed loss than did birds. No birds or bird droppings were observed at sites 2 and 3.

Occasional slug trails were observed on seed lines at sites 1 and 3 . Some loss of legume seed, in particular white clover, was attributed to slugs as the occasional hollowed legume seed husks characteristic of slug feeding were recovered.

Unidentified red ants and small field crickets (Pteronemobius nigrovus) were present around seed lines but were not obseved to feed on the seed. 


\section{Pasture and Forage Crop Pests}

\section{Time of oversowing}

Late summer or early autumn are considered the most suitable times for oversowing of grasses and legumes (White 1973). Early April was an ideal time for oversowing seed in the 1979 season in Northland with conditions suitable for germination and seedling establishment. Heavy rain had fallen at all sites in the 2 weeks preceding the laying down of the trial raising soil moistures $(25-46 \%)$ to levels adequate for germination. Some light rain $(9-14 \mathrm{~mm})$ fell at all sites during the 9 day trial period, maintaining soil moistures. Legume seeds swelled readily and had begun to germinate after 5 days aided by the warm conditions (air temperature maximum $29^{\circ} \mathrm{C}$, minimum $\left.8^{\circ} \mathrm{C}\right)$.

Delaying oversowing until May could be one way of reducing seed losses due to black field crickets as most of the adult crickets will have died off by this time. However, delaying oversowing may also delay germination of seed until the warmer spring months thus enabling weed seeds to establish first. Furthermore, slug activity builds up over the wetter months of the year and hence slugs could be expected to have an adverse effect on clover establishment after a late oversowing. Charlton (1978) obtained almost three times better legume establishment from autumn sowing as compared to spring sowing in North Island Hill Country and this effect was attributed in part to slug attack.

Some farmers in Northland broadcast pasture seed in pasture renovation programmes. Much of this seed is spread before the main autumn rains and would, therefore, be at risk if sown in black field cricket infested areas.

\section{CONCLUSIONS}

Black field cricket infested areas with poor quality open pasture should be baited to eliminate crickets before oversowing in autumn in order to prevent loss of pasture seed.

\section{ACKNOWLEDGEMENTS}

Mr N. Crowe, Mata; Mr R. Hardie, Kiripaka; and the Northern Wairoa Demonstration Farm Committee for trial sites.

\section{REFERENCES}

Blank, R.H., 1979. Black field cricket control is worthwhile. N.Z. J. Agric. 139: 37-8. Blank, R.H., Olson, M.H., Cox, N.R. and Bell, D.S., 1980. Black field cricket Teleogryllus commodus feeding preferences between sixteen pasture species. N.Z.J. Agric. Res. In press.

Blick, C.M., 1959. Pasture damage by crickets. Control methods. N.Z.J. Agric. 98: 217-22.

Charlton, J.F.L., 1978. Control of slug damage in oversown pasture legumes. Proc. 31st N.Z. Weed and Pest Control Conf.: 127-30.

Smith, A.G. and Harrow, K.M., 1971. Black field cricket survival factors. N.Z.J. Agric. 122: $52-4$.

White, J.G.H., 1973. Pasture establishment. In, Pastures and pasture plants. Editor R.H.M. Langer; A.H. \& A.W. Reed Ltd, Wellington. 